\title{
Seasonal Variations in the Morphometric Characteristics of the Pubertal West African Dwarf Buck in its Native Tropical Environment
}

\author{
Variaciones Estacionales en las Características Morfométricas de la Cabra Enana Púber Macho del \\ Oeste Africano en su Medio Ambiente Nativo Tropical
}

"Immanuel I. Bitto \& ** Gabriel N. Egbunike

BITTO, I. I. \& EGBUNIKE, G. N. Seasonal variations in the morphometric characteristics of the pubertal West African dwarf in its native tropical environment. Int. J. Morphol., 24(4):637-642, 2006.

SUMMARY: The effects of season on the morphometric characteristics of the reproductive organs of the pubertal West African Dwarf buck in its native humid tropical environment were investigated. All morphometric characteristics as well as the derivations from both testicular and epididymal morphometry were unaffected by season $(\mathrm{p}<0.05)$. There were however, highly significant correlations $(\mathrm{p}<0.05, \mathrm{p}<0.01, \mathrm{p}<0.001)$ between body weight and testicular as well as epididymal morphometry. The results also showed that both testicular and epididymal morphometric characteristics in the pubertal buck are highly predictable from body weight and as such lend ground for the early selection of good sires from records of their growth rate. The non effect of season on both testicular and epididymal morphometry in this work generally demonstrates that there might be no restricted breeding season for the West African dwarf buck in its native humid tropical environment.

KEY WORDS: Season; Pubertal buck; Testicular morphometry; Humid tropics.

\section{INTRODUCTION}

Sheep and goats occupy an important place in the Nigerian livestock industry, representing about $63.70 \%$ of the total grazing domestic livestock in the country (Gefu and Adu, 1984) with an estimated population of about $56.50 \mathrm{~m}$ (NAPRI,1998). Goats however, outnumber sheep in Nigeria (Valez-Nauer et al., 1982) and present a great potential to mitigate the problem of protein malnutrition in the country as well as supply other products.

The West African Dwarf (WAD) goat, although very popular in Nigeria and adjudged as one of the most prolific in the World in terms of young produced per doe per year (Wilson, 1989 and Gall et al., 1992) is reported to have a poor genetic potential for growth and milk production; thus requiring improvement.

Even though the WAD goat is known to survive under poor management conditions of natural location in the tropics where ambient temperatures and humidity are constantly high all year round (Egbunike \& Dede, 1980), their remarkably high reproductive potential was found to follow the change of dry and rainy seasons (Wilson and Gall et al.) influenced by temperature, humidity and malnutrition status of the animals. These reports were however, based on the number of young produced per female per year and not on the reproductive process in the male. The report of Agiang and Egbunike (1990) on puberty in the male of this breed also bordered only on age and weight at puberty. There is at present a dearth of information on testicular measurements and their application in the prediction of good sires in goats. Testicular measurements and the changes that occur during growth of the testis from birth to maturity have however been well documented for rams (Setchell, 1978; Toishibekov et al., 1984) and bulls (Humphrey \& Ladds, 1975; Willis, 2001 and Dyce, 2002). With no clearly defined breeding season here in the humid tropics, but with significant differences between seasons in ambient and physiologically effective temperatures (Egbunike \& Bitto, 1999) and with

\footnotetext{
* Department of Animal production, University of Agriculture, Makurdi - Nigeria.

**Animal Physiology Laboratory,Department of Animal Science, University of Ibadan,Nigeria.
} 
pubertal bucks successfully serving does as the animals scavenge for food in extensive management; we proposed this study to provide information on the effect of season on the morphometric characteristics of the reproductive organs of the pubertal WAD buck in its native humid tropical environment. Such information will be useful in the early selection of sires for goat breeding and improvement programmes; knowing that testicular development is related to sperm production (Willet \& Ohms, 1957 and Amann, 1970) as well as sperm output and semen quality (Foot $e t$ al., 1970 and Almquist et al., 1976).

\section{MATERIAL AND METHOD}

Seasons: The study was conducted at the Teaching and Research Farm of the University of Ibadan, Nigeria with an equatorial, humid and semi-hot climate already described and classified into four seasons of the year, viz: late dry season (January to March), early rainy season (April to June), late rainy season (July to September) and early dry season (October to December), by Egbunike \& Steinbach (1979) and Egbunike and Steinbach (1980). The seasons of the year in the present study were however modified and limited to only two, namely: The early rainy season and the early dry season.

Animals and management: Eight pubertal bucks, four in the rainy season and four in the dry season were used for this study. The animals in each season had earlier on been weaned between 35 and 40 days of age and were housed together in a group in a standard goat pen with concrete floor. They were fed a maize-based concentrate ration supplemented with forage ad libitum while cool clean water and salt lick were supplied always. They were allowed out of the pen for exercise early in the mornings on days with favourable weather.

Puberty: The preputial smear technique described by Vandenberg (1981) in male golden hamsters, Egbunike (1979) in Large White boars and Agiang \& Egbunike in bucks was applied to the pubertal bucks to determine the onset of puberty. The cotton buds used in the present study were the bel de luxe-Hartmann Ltd. brand. The animals in the rainy season attained puberty at $153.95 \pm 4.08$ days and weighed between 8.86 and $11.00 \mathrm{~kg}$ while those in the dry season attained puberty at $154.62 \pm 5.04$ days and weighed between 8.40 and $11.97 \mathrm{~kg}$.

Samples: All the animals in the respective seasons were sacrificed on the same day. After slaughter, the reproductive tracts were removed in toto and quickly taken to the laboratory. The testes, epididymis and ductus deferens were dissected out and carefully trimmed free of adhering fat and connective tissue for morphometric analysis.

Statistical analysis: Data obtained were subjected to the student's 't' test (Steel \& Torrie, 1980) for a comparism of the seasons, after which the relationships (linear coefficients) between body weight and testicular as well as epididymal morphometry were assessed. Quadratic regression analysis was then used in the prediction of testicular and epididymal morphometric characteristics from body weight.

\section{RESULTS AND DISCUSSION}

Fig. 1 shows the gross anatomy of the testis of the pubertal WAD buck, while a summary of the effect of season on the morphometric characteristics of the reproductive organs and the influence of season on derivations from testicular as well as epididymal morphometry are shown in Tables I and II, respectively.

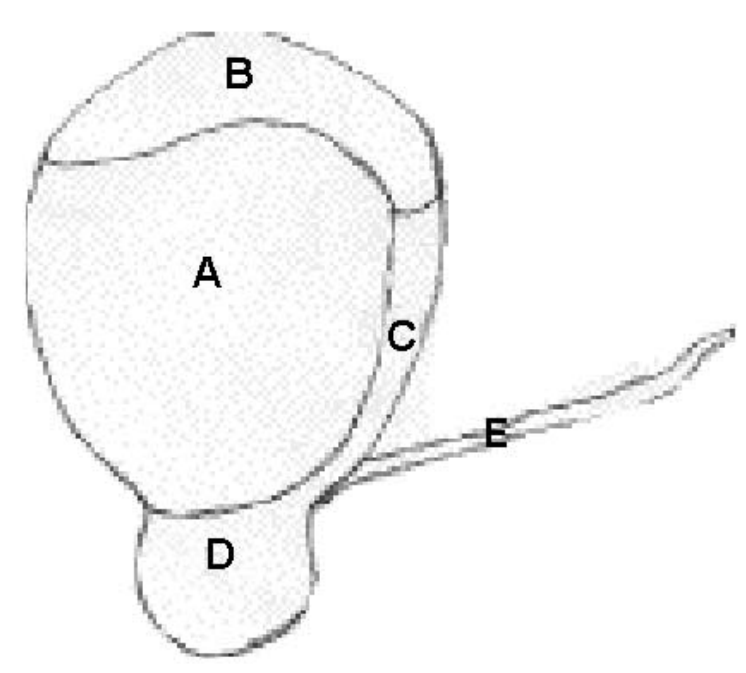

Fig. 1 The gross anatomy of the testis and epididymis of the pubertal WAD buck showing: A.Testis; B. Caput epididymis; C. Corpus epididymis; D. Cauda epididymis; E. Ductus deferens.

All morphometric characteristics as well as their derivations were unaffected by season $(\mathrm{p}<0.05)$. There were however highly significant positive corrections $(\mathrm{p}<0.05$, $\mathrm{p}<0.001$ ) between body weight and testicular as well as epididymal morphometry (Table III), except the relationships between most of the other morphometric characteristics and mean testis density which were significant but all negative. The prediction equations for testicular and epididymal 
Table I. Seasonal variations in the morphometric characteristics of the reproductive organs of the pubertal WAD buck means + sem.

\begin{tabular}{|c|c|c|c|c|c|c|c|c|}
\hline $\begin{array}{c}\text { Parameter } \\
\text { Season }\end{array}$ & $\begin{array}{c}\text { Paired testis } \\
\text { weight }(\mathrm{g})\end{array}$ & $\begin{array}{c}\text { Paired } \\
\text { tunica } \\
\text { albuginea } \\
\text { weight }(\mathrm{g})\end{array}$ & $\begin{array}{c}\text { Mean testis } \\
\text { density }\end{array}$ & $\begin{array}{l}\text { Paired caput } \\
\text { epididymal } \\
\text { weight }(\mathrm{g})\end{array}$ & $\begin{array}{c}\text { Paired } \\
\text { corpus } \\
\text { epid idymal } \\
\text { weight }(\mathrm{g})\end{array}$ & $\begin{array}{c}\text { Paired } \\
\text { cauda } \\
\text { epididymal } \\
\text { weight }(\mathrm{g})\end{array}$ & $\begin{array}{c}\text { Paired } \\
\text { epididymal } \\
\text { weight }(\mathrm{g})\end{array}$ & $\begin{array}{c}\text { Paired } \\
\text { ductus } \\
\text { deferens } \\
\text { weight }(\mathrm{g})\end{array}$ \\
\hline $\begin{array}{l}\text { Early rainy } \\
\text { season }\end{array}$ & $\begin{array}{c}33.48 \pm 3.77 \\
0.65 \pm 0.13\end{array}$ & $1.90 \pm 0.13$ & $1.03 \pm 0.005$ & $1.53 \pm 0.08$ & $0.57 \pm 0.08$ & $1.55 \pm 0.10$ & $3.65 \pm 0.26$ & $0.65 \pm 0.13$ \\
\hline $\begin{array}{l}\text { Early dry } \\
\text { season }\end{array}$ & $\begin{array}{c}23.58+3.52 \\
0.50 \pm 0.03\end{array}$ & $1.52+0.13$ & $1.03+0.004$ & $0.95+0.23$ & $0.68+0.09$ & $1.26+0.21$ & $2.89+0.13$ & $0.50+0.03$ \\
\hline Mean & $\begin{array}{c}28.53+3.46 \\
0.57 \pm 0.05\end{array}$ & $1.71+0.13$ & $1.03+0.00$ & $1.24 \pm 0.20$ & $0.62+0.03$ & $1.40+0.10$ & $3.27+0.26$ & $0.58+0.05$ \\
\hline
\end{tabular}

Table II. Seasonal variations in the derivations from the morphometric characteristics of the reproductive organs of the pubertal WAD buck. (means+sem).

\begin{tabular}{lcccccc}
\hline Parameter & $\begin{array}{c}\text { Paired testes } \\
\text { weight/body } \\
\text { weight } \\
(\%)\end{array}$ & $\begin{array}{c}\text { Paired } \\
\text { epididymal } \\
\text { weight/body } \\
\text { weight } \\
(\%)\end{array}$ & $\begin{array}{c}\text { Paired tunica } \\
\text { albuginea } \\
\text { weight/paired } \\
\text { testes weight } \\
(\%)\end{array}$ & $\begin{array}{c}\text { Lest } \\
\text { Left: Right }\end{array}$ & $\begin{array}{c}\text { Right } \\
\text { Epididymal } \\
\text { weight } \\
\text { Left: Right }\end{array}$ & $\begin{array}{c}\text { Weight of } \\
\text { ductus deferens } \\
\text { Left: Right }\end{array}$ \\
$\begin{array}{l}\text { Early rainy } \\
\text { season }\end{array}$ & $0.94+0.09$ & $0.10+0.08$ & $5.87 \pm 0.46$ & $100: 98.06$ & $100: 99.25$ & $100: 96.96$ \\
$\begin{array}{l}\text { Early dry } \\
\text { season }\end{array}$ & $0.62+0.08$ & $0.07+0.01$ & $6.64+0.43$ & $100: 95.99$ & $100: 96.75$ & $100: 100$ \\
Mean & & & & & & $100: 98.93$ \\
\hline
\end{tabular}

Table III. Correlations between body weight, testicular and epididymal morphometry in the pubertalWAD buck (means \pm sem).

\begin{tabular}{|c|c|c|c|c|c|c|c|}
\hline & & 6 & 5 & 4 & 3 & 2 & 1 \\
\hline 1 & Body weight & $0.62 * *$ & $0.69 * *$ & $0.88^{* * *}$ & $0.90^{* * *}$ & $0.92 * * *$ & - \\
\hline 2 & Paired testes weight & $-0.43 *$ & $0.67 * *$ & $0.90^{* * * *}$ & $0.97 * * *$ & - & \\
\hline 3 & Paired tunica albuginea weight & $-0.44 *$ & $0.68 * *$ & $0.90^{* * *}$ & - & & \\
\hline 4 & Paired epididymal weight & -0.28 & $0.43^{*}$ & - & & & \\
\hline 5 & Paired ductus deferens weight & $0.67 * *$ & - & & & & \\
\hline 6 & Mean testis density & - & & & & & \\
\hline
\end{tabular}

Table IV. Prediction equations for testicular and epididymal morphometric characteristics from body weight based on quadratic regression analysis.

\begin{tabular}{llcl}
\hline Dependent variable (Y) & $\begin{array}{l}\text { Regression equations } \\
\mathrm{X}=\text { Body weight }\end{array}$ & $\mathrm{r}$ & $\mathrm{R}^{2}$ \\
\hline Paired testis weight & $\mathrm{Y}=4.73-0.35 \mathrm{x}+1.84 \mathrm{x}^{2}$ & $0.92^{* * * *}$ & $0.84^{* * *}$ \\
& $\mathrm{Y}=-0.23+0.56 \mathrm{x}-0.01 \mathrm{x}^{2}$ & $0.90^{* * *}$ & $0.81^{* * *}$ \\
Paired tunica albuginea weight & $\mathrm{Y}=1.57-0.74 \mathrm{x}+0.34 \mathrm{x}^{2}$ & $0.88^{* * *}$ & $0.78^{* * *}$ \\
Paired epididymal weight & $\mathrm{Y}=0.39+0.33 \mathrm{x}-0.02 \mathrm{x}^{2}$ & $\mathbf{0 . 6 9 * *}$ & $0.47^{* *}$ \\
Paired ductus deferens weight & $* * *=\mathrm{p}<0.001$ & &
\end{tabular}


morphometric characteristics from body weight based on quadratic regression analysis are shown in Table IV, with highly significant relationships in all cases.

Both the age and weight at puberty obtained in the present study agree with the overall mean age and live weight of $153.26+8.45$ days and $9.33+0.42 \mathrm{~kg}$, respectively, earlier reported in the same breed at puberty by Agiang \& Egbunike.

The similarities between the rainy and dry seasons in all the morphometric characteristics studied indicate that unlike in the females of the same breed where the reproductive potential was found to change with season (Wilson; Gall et al.), seasons may not affect the development of the reproductive organs in males even though these workers implicated temperature, humidity in addition to nutritional status as influencing the reproductive potential in females. The noneffect of seasons on testicular morphometry in the present study may be explained by the fact that ambient temperature is considered as a secondary factor (after day length) affecting reproductive capacity in male small ruminants (Thimonier et al., 1986). Roca et al., (1992) also reported that the semen quality of Murciano Granadian male goats was not affected by the high temperatures of the Mediterranean summer. With animals on a good plane of nutrition as in the present study, all reproductive processes that are dependent on or related to organ weights like sperm production and the efficiency of sperm production, sperm storage capacity and seminal characteristics would therefore be expected to be stable in the buck all year round.

The good and positive correlations between body weight and all morphometric characteristics (except mean testis density) as well as the significant relationships among morphometric characteristics indicate the possibility of predicting organ weights and fertility from body weight and thus enhancing the early selection of good sires since sperm production is related to organ weights (Willet \& Ohms, and Amann).

\section{CONCLUSION}

The results of this study indicate that there might be no restricted breeding season for the WAD buck in its native environment. Normal breeding programmes could therefore be practised all year round. The study also in agreement with earlier reports (Willet \& Ohms; Amann; Foot et al, 1970 and Almquist et $a l$,) lends ground for the prediction of sperm production rates from live animals as well as provides information that will be useful in the early selection of sires for goat breeding and improvement programmes in the humid tropics.

BITTO, I. I. \& EGBUNIKE, G. N. Variaciones estacionales en las características morfométricas de la cabra enana púber macho del Oeste africano en su medio ambiente nativo tropical. Int. J. Morphol., 24(4):637-642, 2006.

RESUMEN: Se estudiaron los efectos que tiene la estación sobre las características morfométricas de los órganos reproductivos de la cabra enana macho del Oeste africano en su medio ambiente tropical húmedo. Todas las características morfométricas, como también las derivaciones de la morfología de ambos testículos y espidídimos, no fueron afectadas por la estación ( $<<0.05$ ). Sin embargo, hubo, correlaciones altamente significativas $(\mathrm{p}<0.05, \mathrm{p}<0.01$ y p $<0.01$ ) entre el peso del cuerpo y del testículo así como la morfometría epididimaria. Los resultados también mostraron que las características morfométricas del testículo y epidídimo en la cabra enana macho púber son altamente predecibles, conociendo el peso del cuerpo, lo que permitiría una temprana selección de buenos padres sementales a partir del registro de sus rasgos de crecimiento. La ausencia de efectos estacionales sobre la morfometría del testículo y epidídimo que se observó en este trabajo, demostró que allí no debería restringirse la época de cría de la cabra enana del Oeste africano en su ambiente nativo tropical.

PALABRAS CLAVE: Estaciones; Macho púber; Morfometría testicular; Trópico húmedo.

\section{REFERENCES}

Almquist, J. O.; Branas R. J. \& Barber K. A. Post Pubertal Changes in semen production of Charolaris bulls ejaculated at high frequency and the relation between testicular measurements and sperm output. J. Anim. Sci. 42:670, 1976.
Agiang, E. A. \& Egbunike, G. N. Age at puberty in the male West African Dwarf goat in a humid tropical environment by the penile smear technique. Trop. Anim. Prod. Invest. 1:28-33, 1990. 
Amann, R. P. Sperm production rates In: The Testis. A.D. Johnson, W. R. Gomes and N. L.Van Demark (Eds.). Academic Press New York, 1970. V. 1. pp 433-82.

Dyce, K. M.; Sack, W. O. \& Wensing, C. J. G. The pelvis and reproductive organs of male ruminants in Textbook of Veterinary Anatomy. $3^{\text {rd }}$ Ed. Saunders. New York, 2002. pp. 713-22,

Egbunike, G. N. Development of puberty in Large White boars in a humid tropical environment. Acta Anat., 104: 234-7, 1979.

Egbunike, G. N. \& Bitto, I. I. Effects of season on the Physiological responses of the West African Dwarf buck to acute exposure to tropical sunlight. Trop. Anim. Prod. Invest., 2:20-7, 1980.

Egbunike, G. N. \& Dede, T. I. The influence of short term exposure to Tropical. Sunlight on boar seminal characteristics. Int. J. Biometeor., 24(2), 1999.

Egbunike, G. N. \& Steinbach, J. Season of variations in the sperm Production rates of boars in a humid tropical environment. Niger. J. Agric. Sci., 1:21-6, 1979.

Egbunike, G. N. \& Steinbach, J.Seasonal changes in sow fertility in a humid tropical environment. Zentralblatt fur Veterinarmedizin, A 27:109-17, 1980.

Foot, R. H.; Hahn, J. \& Larson, L. L. Testicular measurements as predictors of sperm output and semen quality. Proc. $3^{\text {rd }}$ Tech. Conf. On AI and Reprod., 1970.

Gall, C. H.; Stier, C. H. \& Younan, M. Small ruminants in developing Countries, Target for biotechnology. Symp. of potentials and limitations of biotech for livestock breeding and production in developing countries. Mariense Germany, 119-30, 1992.

Gefu, J. O. \& Adu, I. F. Understanding small ruminant production in Northern Nigeria. World Review of Anim. Production, 20(3):35-9, 1984.

Hann, J.; Foote, R. H. \& Seidel, G. E. Testicular growth and related sperm output in dairy bulls. J. Anim. Sci., 29: 41-7, 1969.

Humphrey, J. D. \& Ladds, P. W. A quantitative histological study of changes in the bovine testes and epididyrmis associated with age. Res. In Vet. Sci., 19:135-41, 1975.
NAPRI, 1998. National Animal Production Research Institution, Ahmadu Bello University, Shaki, Zaria, News Letter, 1998.

Roca, J.; Martinez, E.; Vazquez, J. M. \& Coy, P. Characteristics and seasonal variations in the Semen of Murciano-Granadina goats in the Mediterranean area. Anim. Reprod. Sci., 29:255-62, 1992.

Setchell, B. P. The Mammalian testis. Paul Elek. London, 1978.

Shrestha, J. N. B.; Fisher, P. S.; Langford, G. A. and Heaney, D. P. Influence of breed, birth date, age and body weight on testicular measurements of growing rams maintained in a controlled environment. Canadian, J. Anim. Sci. 63(4):835-47, 1983.

Steel, R. G. D. \& Torrie, J. H. Principles and procedures of statistics, A Biometrical Approach. Mc Graw - Hill. Book Co. Inc., New York, 1980.

Thimonier, J.; Terqui, M. \& Chemineau, P. Conduite de la reproduction de petits ruminants dans les differentes parties du monde. Proc. Int. Atomic Energy Agency. Vienna, 135-47, 1986.

Toishibekov, M. M.; Perekalin, Yu. A. \& Kamyrov, A. Postnatal development of the testes and some semen traits in crossbred rams of desssirable tyhpe. Trudy Instituta Eksperimental noli Biologii. Akademiya Nauk Kazakhskoi SSR, 1984.

Valez-Nauer, M.; Carew, B. A. R.; Mosi, A. K.; Opasina, B. A. and Haywood, B. Productivity of The West African Dwarf goat at village level in South West Nigeria. Proc. 3rd. Int. Congr. On goat Production and disease Tucson, Arizona, 1982. pp. 356.

Vandenberg, J. G. The Penile Smear:an index of sexual maturity in male golden hamsters. Biol. Reprod. 4:234-7, 1981.

Willet, E. L.\& Ohms, J. I. 1957. Relation of testicular size to production of spermatozoa by young and aged bulls. J. Dairy Sci., 40:622, 1957.

Willis, B. M. Breeding policies in developing regions. In Dalton's Introduction to practical animal breeding. 4. ed. Blackwell Science, 2001. pp. 132-8.

Wilson, R. T. Reproductive performance of African indigenous small ruminants under various management systems, a review. Anim. Prod. Sci. 20:265-86, 1989. 
BITTO, I. I. \& EGBUNIKE, G. N.

Correspondence to:

Dr. Inmanuel Bitto

Department of Animal production

University of Agriculture

Makurdi

$\mathcal{N I G E R I A ~}$

Email: sibittos@yafioo.com
Received: 29-05-2006

Accepted: 14-09-2006 